\title{
3D geological-geophysical model and chronological rock sequence of the Suwałki Anorthosite Massif - NE Poland
}

\author{
Z.PETECKI ${ }^{1}$, O.ROSOWIECKA ${ }^{1}$, \\ J.B.WISZNIEWSKA ${ }^{1 *}$, E.KRZEMIŃSKA ${ }^{1}$ \\ ${ }^{1}$ Polish Geological Institute - National Research Institute, \\ 4, Rakowiecka str., 00-975 Warsaw, Poland ("correspondence: \\ janina.wiszniewska@pgi.gov.pl)
}

The Mesoproterozoic Suwałki Anorthosite Massif (SAM), located in NE Poland is completely covered by ca. $1000 \mathrm{~m}$ thick Phanerozoic sequences. It was not fully recognized by deep boreholes that have been mainly focused on anomaly area for Fe-Ti-V deposit prospects. Thus, an understanding of 3D structure of the SAM was the crucial point in recent study. To contribute to this aim geological and 2.5-D forward modelling of gravity and magnetic data were used to create preliminary geological models along profiles. The key crustal units and their structure were imported into GeoModeller software package that highlighted in 3-D the large volume of anorthosites in the centre of the SAM and other surrounded rock complexes. Geochronological order was a crucial parameter for modelling physical and chemical processes taking place during formation of the SAM including stages of the massif emplacement and their mechanism.

The SHRIMP IIe technique has been also used to establish a chronology of batholith emplacement (zircon) and their later evolution (monazite, titanite). The U-Pb bearing minerals separated from anorthosites and norites and also from crosscutting granite veins, pegmatites and aplites, document evolution of the SAM started at 1.53-1.50 Ga and terminated by crystallization granite vein at $1495 \pm 11 \mathrm{Ma}$ and pegmatite at $1488.7 \pm 4 \mathrm{Ma}$ [1], which is the youngest magmatic episode recorded within the SAM. Thermochronological ${ }^{40} \mathrm{Ar}-{ }^{39} \mathrm{Ar}$ investigation of igneous biotite collected from several type of rocks and drill cores within the SAM document a subsequent slowly cooling process below $300^{\circ} \mathrm{C}$ temperature between 1464 and $1412 \mathrm{Ma}$, thus this temperature was reached 100 years after initial AMCG intrusions.

[1]Wiszniewska, Krzemińska, 2017. MINERALOGIASpecial Papers, 47: 40.

The research was financed by $\mathrm{NCN}$ grant no. 2015/17/B/ST10/03540 